\title{
Analysis of users of computer games
}

\author{
Witold Chmielarz \\ University of Warsaw Faculty of \\ Management ul. Szturmowa 3 02- \\ 678 Warszawa, Poland \\ Email: witold.chmielarz@uw.edu.pl
}

\author{
Oskar Szumski \\ University of Warsaw Faculty of \\ Management ul. Szturmowa 3 02- \\ 678 Warszawa, Poland \\ Email: oskar.szumski@uw.edu.pl
}

\begin{abstract}
The main aim of this article is to show the characteristics of individuals playing computer games and their styles of play. In order to present the relevant data, the authors limited the study sample to a selected group of individual users. In the current paper the authors presented the commonalities of gamers, their approach towards participation in games, and the awareness of potential changes and improvements in the area. They also held discussions concerning the obtained solutions and drew conclusions based on the present stage of research.
\end{abstract}

\section{INTRODUCTION}

The main aim of this work is to analyze the use of computer games as one of the alternative forms of entertainment in the selected group of users under the circumstances of a dynamic development of devices and mobile applications running on them. The aim of this article is to analyze the situation where computer games are used by people who treat them not only as a form of entertainment but also as a kind of sport. The popularity and specific universal nature of the access to computer games facilitates a fast development of information technologies. A broadly defined concept of mobility also impacts the use of computer games, moving the focus from using PCs to the use of smartphones and tablets.

According to the statistics of Newzoo [12] service, in Poland in 2013 the number of gamers amounted to 13.4 million, out of which $98 \%$ used their PCs to play computer games (together with other platforms). We take the second position in Europe among the examined countries. The market of computer games in Poland is growing every year - in the end of 2014 it was worth about 280 million dollars and it will be growing by $3.8 \%$ a year, thus increasing the value of the entire market to 437 million dollars at the end of 2016 [9]. Hence, undoubtedly the subject matter is worthy of attention.

Unfortunately, the phenomenon itself is difficult to define and examine taking into account the formalized scientific analyses. Firstly, there is no clear definition of computer games $[8,10,11,13,15,20,24]$. In its narrow sense, this concept is treated literally as games in the form of software running only on traditional hardware such as (desktop, microcomputers, laptops or palmtops). In its broad, historical approach, the group encompasses also games running on devices such as a console, TV, gaming machines, smartphones and tablets (which are in fact communication and application computers). As the games running on all kinds of devices were being developed in parallel, and, in fact, there are PC equivalents of all kinds of games, we sometimes use this term in its broad meaning. Thus, for the needs of this study, the authors assumed that computer games are a generic term (hypernym) encapsulating the whole class of all kinds of games presented as a homogenous phenomenon. Secondly, there is no one generally accepted definition of a person playing computer games (e-gamer). Thus, in the narrow sense of the word, an e-gamer is a person who plays computer games every day or a few times a week, individually or taking part in a multi-player game. Sometimes, the scope of this term is limited to include only those players who treat MMO (Massively Multiplayer Online games) class games as a sport, and they try to play them professionally. However, we observe a more and more common tendency to expand the term to include also any individuals who play any kind of game from time to time, perceiving it as just one more alternative kind of entertainment. This article treats the concept of e-gamers in such a way. Thirdly, there is no (specific or clear) classification of computer games: there are a number of typologies based on various criteria, most frequently taking into account the type of activity required from the egamer playing games (e.g. logic, strategic, arcade, RPG (role-playing games), MMO (Massively Multiplayer Online games) etc., with a number of varying kinds and versions.

The phenomenon of computer games has been examined in numerous studies, in numerous countries and social groups [e.q. 4, 6, 7, 22, 25], including large-scale studies [e.g. 5, 21, 26]; nevertheless, they were carried out before the recent period of extreme popularity and growth in the number of applications running on smartphones and tablets. And the second point is - that they are concentrated on statistics of the players (with their features) or social field of problem rather then on IT development. The authors hoped to establish certain implications of the new phenomena with regard to the direction of computer games development. Therefore, the authors have undertaken the studies whose main aim is to analyze the use of such applications among users. The findings presented in this article constitute a brief report on the first stage of the research conducted among the gamers in Poland in 2015. 
II. The ASSUMPTIONS OF RESEARCH METHODOLOGY AND POPULATION SAMPLE

Due to limited and fragmentary research concerning the area of internet computer games and e-gamers, both from the point of view of an individual client and a group of cus tomers, in Polish and foreign literature, the studies have been based on the authors' own approach [1], quite different from surveys in Poland [25,26] and some different from research in the other countries $[18,19]$, consisting of the following steps:

- analysis of a selected group of players on the basis of a quantitative and qualitative survey, divided into the following parts:

- characteristics of a computer player and identifying his or her preferences in computer games,

- identification of potential effects and consequences of playing computer games for egamers.

-placing an internet version of a survey on the servers of the Faculty of Management of the University of Warsaw, conducting functionality test and its verification,

- carrying out the survey among the users, analysis and discussion of the findings,

-drawing conclusions from the obtained results concerning the current situation and possible directions of the future development of internet computer games on the basis of the users' opinions.

The article presents the results of the analysis of the first part of the completed survey. It allowed for identifying a particular group of people who play various kinds of games, using different kind of hardware and software, with a varying level of skills and expectations concerning the organizational and technical aspects of playing games. Only after the selecting the group of best, "professional" players, we may proceed to specify the implications and psychophysical effects of their involvement in individual and multi-player games. The latter aspect was examined in the second, sequentially conducted, stage of the survey, whose results and conclusions will be presented in subsequent publications [3].

The questionnaire surveys were conducted near the end of December 2015. The selection of the study sample was not accidental: it belonged to the category of convenience sampling, the respondents were mainly students of selected universities in Warsaw (University of Warsaw and Vistula University (Akademia Finansów i Biznesu Vistula)), of full-time and part-time BA, BSc and MA studies. The survey was also completed by two members of university staff who declared playing computer games. The surveys were circulated electronically, and the response rate did not exceed $70 \%$. Students are particularly open to all kinds of innovation, especially if it concerns their private life or entertainment [23].

A specific limitation concerning this particular sample was an anticipated high percentage of smartphone, tablet, laptop and mobile phone users, devices of lower quality but with a longer durability. An additional argument for con- ducting research in this social group was the demand from company cooperating with us on the design and construction of specific game platforms. The company depended on the wide market recognition of students as the main customer of such a platform.

The survey was completed by 274 people, out of which 254 participants submitted correctly completed questionnaires (which constitutes $92.70 \%$ of the sample). Among the respondents there were $59.45 \%$ of women and $40.16 \%$ of men; $0.39 \%$ respondents did not answer this question. An average age of the respondent was 20.62 years, and the medium value was 19 years. The age is typical of students of the first years of BA and BSc students and the first years of the studies of the second cycle - the group asked to complete the questionnaires. The oldest person taking part in the survey (member of the university staff) was 37 . Among the survey participants there were $63.39 \%$ of students, $35.83 \%$ working students and $0.79 \%$ employees. $70.87 \%$ indicated secondary level education and $20.08 \%$ post-secondary education - the survey was primarily conducted among the students of BA studies. $8.66 \%$ declared holding a BA degree or a certificate of completion of studies, only one person indicated having a $\mathrm{PhD}$ degree.

Over $45 \%$ of survey participants indicated that they are inhabitants of cities with over 500,000 residents, over $14 \%$ came from cities with 100,000-500,000 of inhabitants, over $21 \%$ from towns with $10,000-100,000$ residents, almost $5 \%$ from towns up to 10,000 residents, and $12.6 \%$ declared that they come from rural areas. The simplicity of the survey did not cause many distortions during its completion; few respondents (17) completed also additional sections of the survey.

\section{ANALYSIS OF THE FINDINGS AND DISCUSSION}

Respondents provided answers to forty-one substantive questions, out of which responses to first twenty-one questions concerned the issues which are the aim of this article. The first group of questions concerned the characteristics of e-gamers and their use of computer games.

Nearly $40 \%$ of respondents provided positive answers to the question concerning frequent use of computer games, i.e. every day (20\%) and a few times a week (over 19\%). This is the score which is 10 percentage points lower than rare use of e-games, which amounts to more than $49 \%$. After preliminary interviews with respondents it seemed that the interest in computer games will be higher. The high score of a reasonable way of playing computer games (a few times a month) $-22 \%$ showed that the games are just one of many alternative kinds of entertainment available today. Fig. 1 illustrates the findings of the research.

Taking into account the technical aspects concerning platforms which e-gamers use, in the last 12 months we observe a specific shift towards mobile devices, smartphones in particular. Thus, over $35 \%$ of e-gamers $(80.75 \%$ including other platforms) used mobile platforms (mainly Android) last year. The second place was taken by PC platform $28.31 \%$ (65.24\% including other devices), and the third position was occupied by the console (e.g. Xbox, PS) with the 


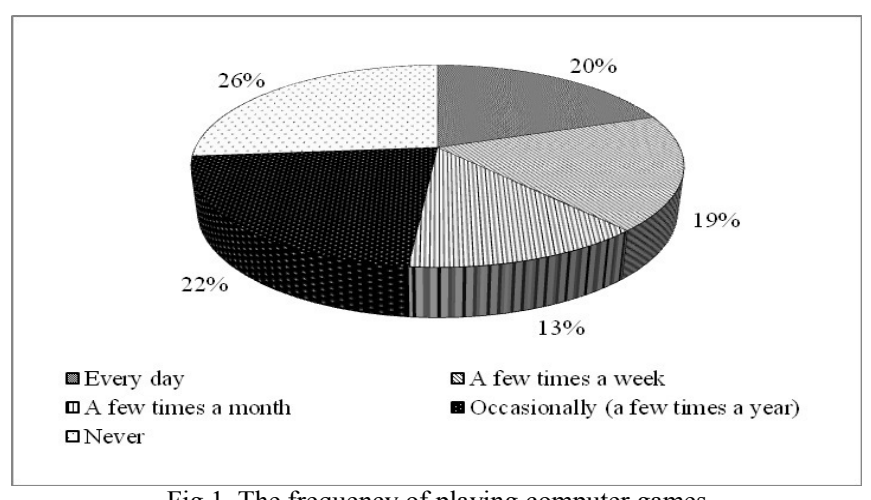

Fig 1 . The frequency of playing computer games

score of 27.38 (63.10\% - respectively). Smart TV platform received the lowest scores in this ranking $-2.09 \%$ (4.81).

In the perception of particular platforms among the egamers, we notice considerable discrepancies, amounting to 33 percentage points. The greatest number of respondents simultaneously use smartphones and PCs as platforms for games. Here, the dispersion of the results reaches almost 76 percentage points. The observed tendencies are presented in Fig. 2.

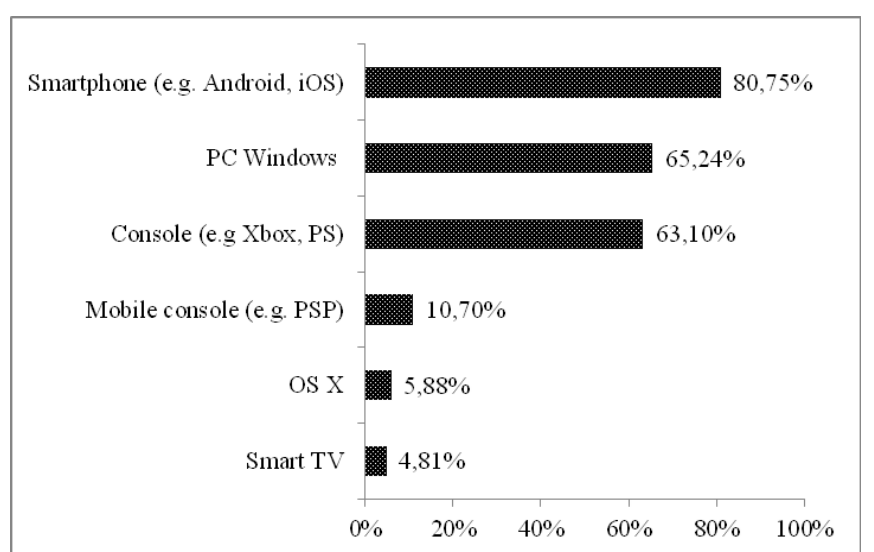

Fig 2 . The platforms which were most frequently used as e-games platforms in the last year

On the other hand, it probably stems from the fact that the majority of e-gamers $59.87 \%$ (including other kinds of game access $-97.33 \%$ ) use the games installed on a device (a PC or a smartphone). The second position of Steam, Origin etc. platforms amounting to $26.32 \%$ (respectively $42.78 \%$ ) is a rather interesting phenomenon. The two main sources of games together constitute over $86 \%$ of "places" where egamers used the possibility of playing games in the last year. The remaining places where games were downloaded e.g. Facebook (6.25\%) and low score of browsers (e.g. Quake Live) $-7.57 \%$ seem to be of marginal importance in this relation. The Fig. 3 illustrates the scores.

The responses to the question concerning the age of egamers at the moment when they started to play games brought about very interesting results. The age which was most frequently indicated by respondents (almost $50 \%$ of responses) was within the range of 6-9 years (median of 6-7 years). If we add a group of people aged 10-11, we have

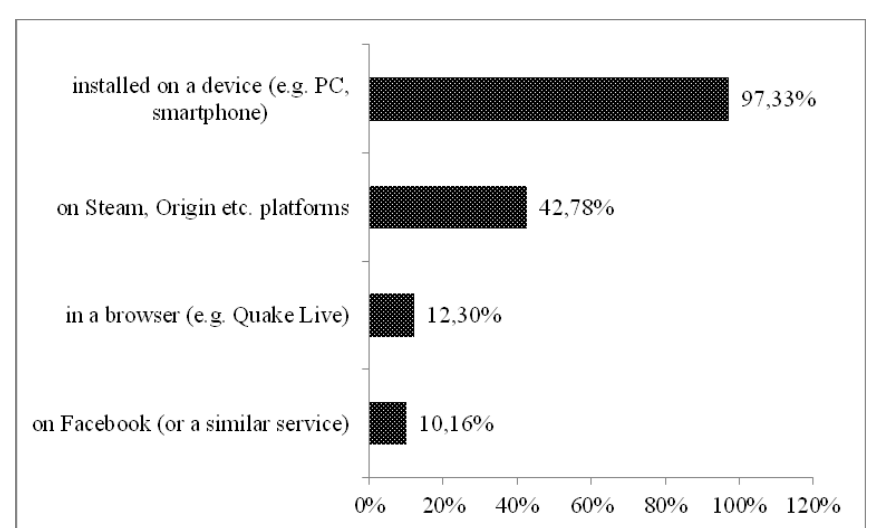

Fig 3. Places where e-gamers installed games

more than two thirds of all gamers! It is also significant that $17.11 \%$ of e-gamers declare that they started being interested in games at the age of 5 . A marginal number $(1.07 \%)$ admits starting playing games at the age of 20-25 (and the group that indicated the age of 16-25 amounted to $2.76 \%$ ). This indicates the very early age when people become interested in computer games and treating the games as an alternative kind of entertainment in relation to films, TV, games or outdoor activities. Unfortunately, the limitation of the research was the fact that the authors did not examine children and young people from this age group. Nevertheless, the obtained results explain where - among others - the interest in computer games later in life comes from. The responses of survey participants were presented in Fig. 4.

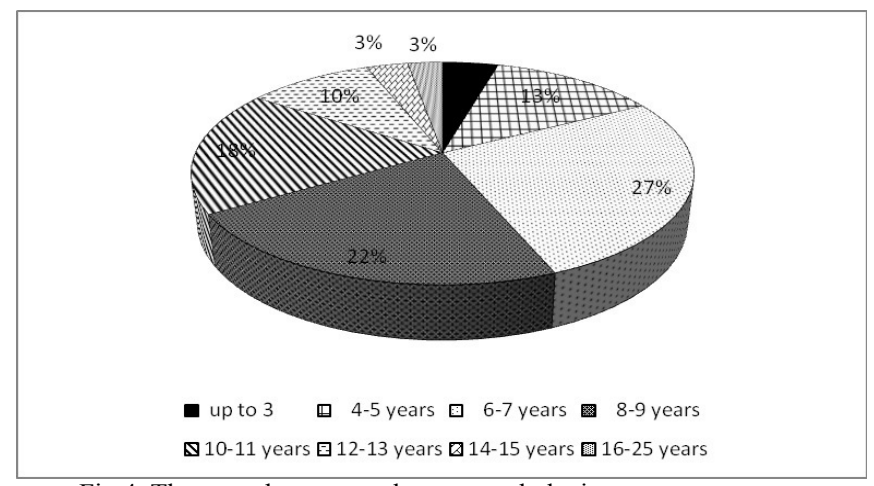

Fig 4 . The age when respondents started playing computer games

Subsequently, the authors examined also the amounts of money which e-gamers spend monthly at playing computer games. The vast majority of them $-79.14 \%$ - use free applications installed on smartphones or free (or, as some people claim, illegally downloaded from the Internet) PC games. The remaining $18.18 \%$ of respondents are willing to pay up to PLN 80 monthly, and only $2.67 \%$ from PLN $81-300$. From the commercial point of view, the last group (in particular $2.14 \%$ of survey participants who are willing to pay between PLN 151-300) is most interesting to examine because it includes mainly hobbyists, enthusiasts and fanatics - as it seems - professional e-gamers. The representatives of this group are interested in sport, which in this case is realized by means of various electronic tools $(\mathrm{PC}$, smartphone or 
tablet, console, etc.). The study results are presented in Fig.5.

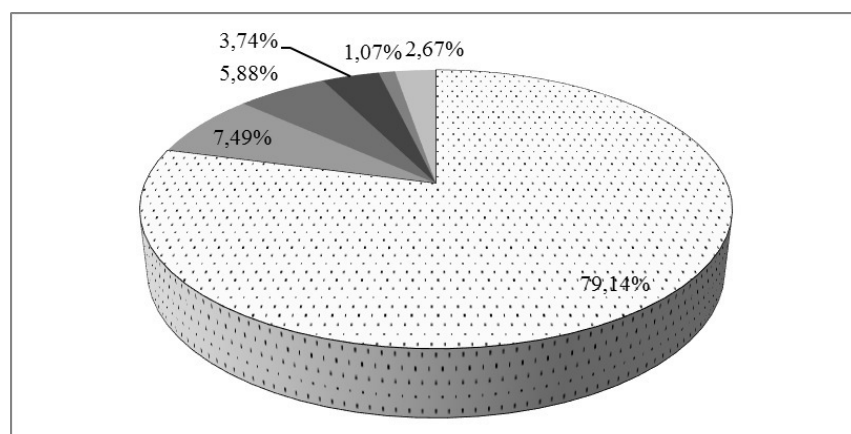

๑PLN 0 = up to PLN 20 - PLN 21-40 $\mid$ PLN 41-60 $\mid$ PLN 61-80 $=$ PLN 81-300

Fig 5. Monthly payments for playing computer games

The subsequent questions were used to evaluate the situation. Their goal was to indicate what kind of games the egamers played most frequently in the last year. The games were divided according to the typology indicated by the most frequent e-gamers:

- arcade games (shooting, fighting) (e.g. Counter Strike, Tom Clancy's Rainbow Six, Super Mario),

- action-adventure games (e.g. Assassin's Creed, Half-Life),

- adventure games (e.g. The Walking Dead, Wallace \& Gromit),

- $\quad$ RPG (role-playing games) games (e.g. Diablo, Fallout),

- $\quad$ simulation games (e.g. The Sims, FIFA 16, Need for Speed),

- strategic games (e.g. StarCraft II, Civilisation, Warhammer, Heroes of Might and Magic),

- $\quad$ survival horror games - (e.g. Resident Evil),

- Massively Multiplayer Online games -MMO and their variants (e.g. World of Warcraft, Lord of the Rings Online).

Subsequently, the respondents answered the questions related to whether they played a particular kind of game in the period of last year. The questions formulated in such a way seemed to allow for more accurate responses that the ones which referred to the type of games they played most frequently. The authors worried that the responses concerning the last few months would dominate in the survey. They did not examine the recent trends in the market, the influence of newly published books and films related to particular themes, etc. The greatest number of positive responses, $80.75 \%$, was indicated in the case of the simplest type of games - e.g. simulation games. The group of simple games also includes arcade games $(57.75 \%)$ and action-adventure games $(50.27 \%)$, where the number of positive responses exceeded $50 \%$. In general, the greater complexity, the more complex relations, or the duration and additional limitations, the smaller the percentage of e-gamers admitting that they play a particular kind of game. The external factors, such as the history (the game was on the market "since I remember"), the popularity of a hero or a heroine or a plot constructed and popularized in films, books, board games, etc. contribute to the preeminence of the game. The games where the gamer needs to be more involved and stay in one place are less popular. The results of this part of the study are presented in Fig. 6.

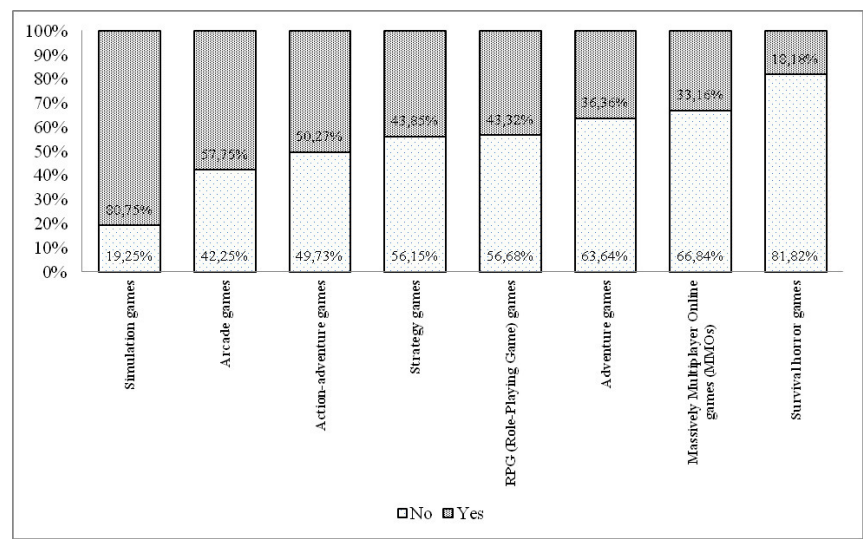

Fig 6. The most popular and most frequently played kinds of games

A good indication of the level of the engagement of the player is his or her willingness to choose to spend time in a game over other kinds of entertainment. The respondents were asked two questions if they 1) ever or 2) within the period of last year have chosen to spend time in a game over other, alternative forms of entertainment, such as:

- going to the cinema,

- meeting friends,

- going on a date,

- going for a trip with friends,

- going to a party,

- no such case.

It turned out that computer games are not enjoyable enough for players to give up anything in the past (61.78\%) or in the last year $(77.40 \%)$. If the respondents are willing to resign from something, it is mainly a meeting with friends $15.11 \%$ and a party $9.78 \%$. In case of giving up anything in the last year in favor of a computer game, the results were similar. The respondents indicated a social meeting $-8.17 \%$ and a party $-6.73 \%$. In reality, the difference indicated in the percentage of people who are willing to give up other forms of entertainment amounts to 17.32 percentage points, and decreases the actual numbers of indications in particular categories - the greatest with regard to social meetings nearly 7 percentage points and parties - over 3 percentage points. The detailed scores are illustrated in Fig. 7.

In the respondents' views, the quality of computer games meets all or most expectations of players in $70 \%$ (Fig 8). The response that the game fulfills e-gamers' expectations to a moderate and limited degree is indicated only by $28 \%$ of respondents. A fraction of the sample evaluated the games as not enjoyable enough to consider giving up other activities 


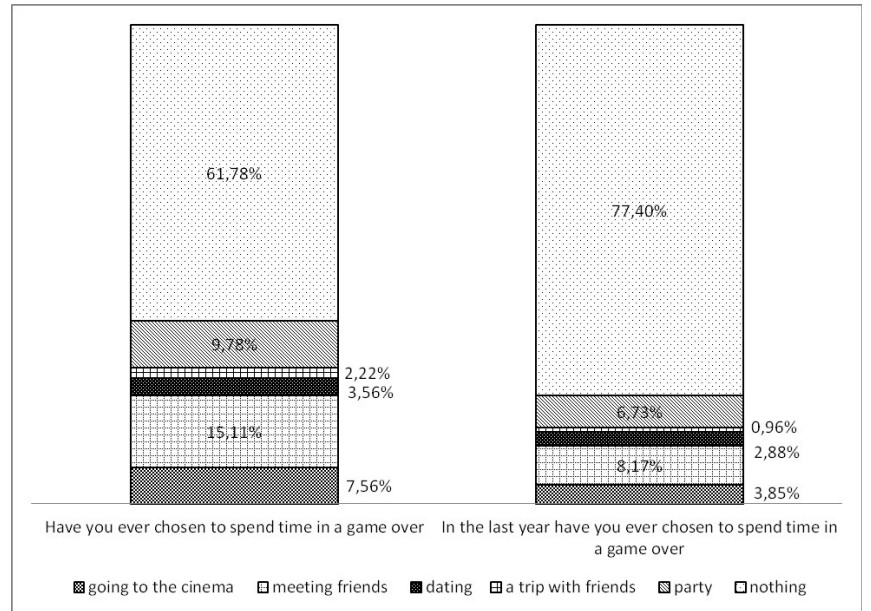

Fig 7. The willingness to give up other forms of entertainment among e-gamers

in favor of spending time in the game. Probably, it is one of the reasons why games are still so popular.

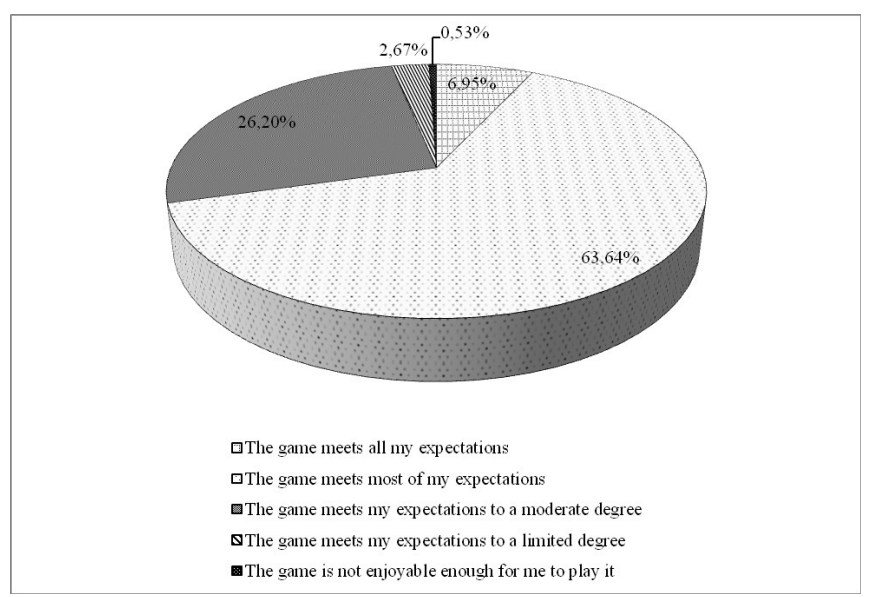

Fig 8 . The quality of computer games in e-gamers' opinions

The vast majority of interviewed e-gamers (64\%) are not interested in being leaders in games (provided that games offer such an opportunity). The remaining options are rather evenly distributed: $11 \%$ - clan leader, $7 \%$ - officer, $6 \%$ - advisor, $4 \%$ - higher-ranked officer and $8 \%$ - playing other roles (Fig. 9).

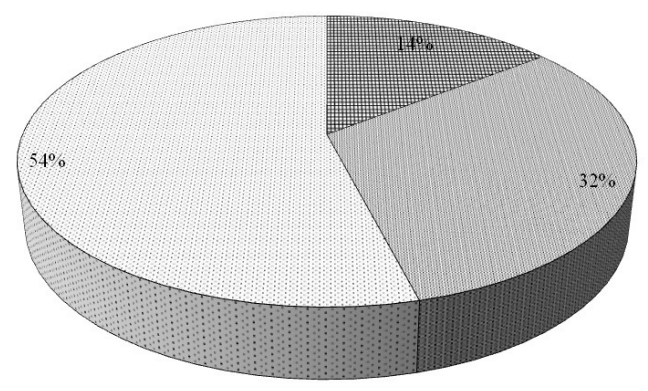

由 You complete one game and start another $\square$ You play simultaneously a few games ๑You play one game and take a break

Fig 9. The frequency of playing computer games
Most e-gamers (54\%) complete one game, take a break and only later start to play another computer game. Nearly $32 \%$ play a few games simultaneously. Only $14 \%$ finish playing one game and immediately start playing another. The frequency of playing games among respondents is shown in Fig. 10.

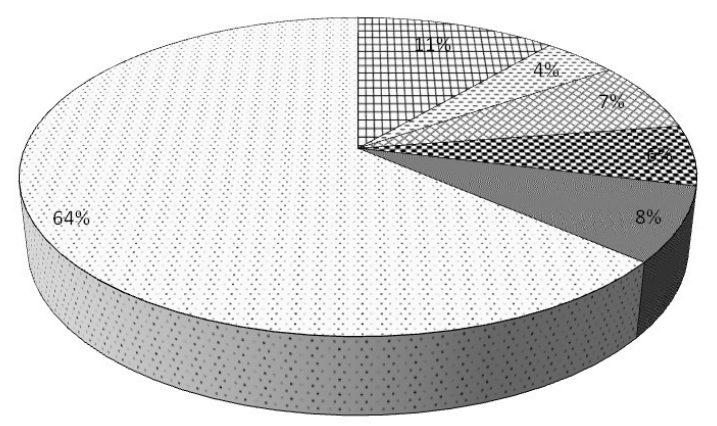

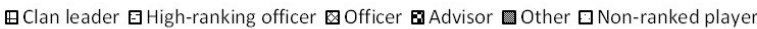

Fig 10. The willingness to be a leader among e-gamers

e-Gamers have a high opinion of their own skills as players (over 60\%): they describe their skills as master level $(18.72 \%)$ or advanced $(42.72 \%)$. The number of gamers who see their skills as intermediate amounts to $33 \%$, and less than $6 \%$ claim that they possess gaming skills at beginner level. Of course, due to the fact that gamers play games for a number of years, and general rules stay the same, egamers usually perceive themselves as specialists at using such opportunities, even if, thanks to new technologies these possibilities are constantly being developed. The structure of the e-gamers' skills is presented in Fig. 11.

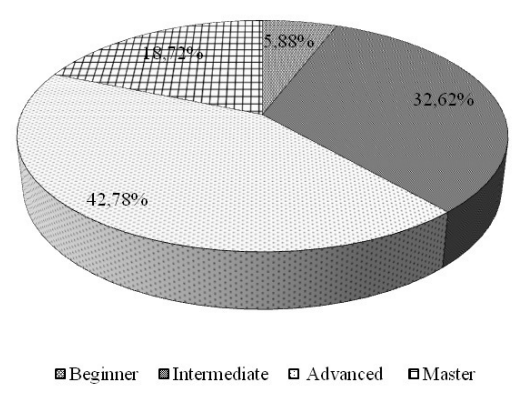

Fig 11. The structure of e-gamers' skills

The two remaining questions concerned the possible hardware conveniences and software advantages. In the first case, the respondents were given the following options to select from:

- obtaining mentor's help,

- using video and text tutorials (from game publishers),

- using in-game help,

- $\quad$ getting help from other gamers (e.g. forum), 
- getting virtual or real payment,

- other advantages,

- no other advantages.

Almost $30 \%$ of gamers do not expect any advantages in this regard. They focus on the game they are currently playing, and they are satisfied with the game itself (passive players). Undoubtedly, the other e-gamers would be more satisfied if they could get help from other game users e.g. forum $(22.14 \%)$, use text and video tutorials $(12.55 \%)$ or in-game help (12.18\%). Their satisfaction (18.08\% of respondents) would increase if they received bonuses (additional options, game paths, etc.) or even actual reward (payment); yet, they have unrealistic or vague expectations concerning the latter. They do not pay attention to other conveniences or advantages of such kind. The results of this query are presented in Fig. 12.

With regard to the technical conveniences, e-gamers were

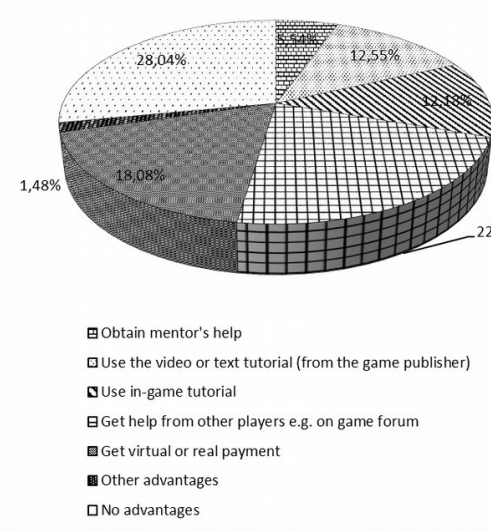

Fig 12. Non-technical conveniences for e-gamers

asked about the following, potential possibilities of changes concerning:

- computer hardware (e.g. graphic card) or a better tablet,

- armchair/seat,

- accessories (e.g. professional mouse, keyboard, earphones),

- better monitor/ VR goggles,

- other,

- I don't want to change anything.

In this case the responses were completely different than in the previous rankings. First of all, the structure of their responses was not evenly distributed. Nevertheless, almost one fourth $(23.53 \%)$ of respondents are not satisfied with the hardware they own that they use to play a game, and they would like to change it. The distribution of the potential changes or lack thereof, was actually similar in relation to the remaining elements: better monitor or goggles $-18.53 \%$, better armchair/seat $-21.76 \%$, better accessories $-16.76 \%$ or no change at all $-16.47 \%$.

Similarly to the previous case, basically e-gamers do not notice any potential for changes - less than 3\% provided positive responses to this question, and there were no signif- icant indications which we could relate to (e.g. additional lighting, additional monitors, etc.). The results are presented in Fig. 13.
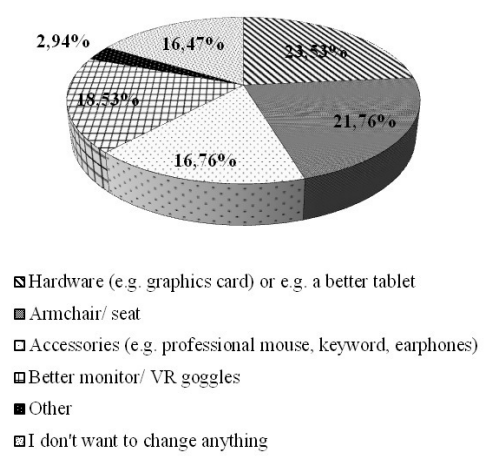

Fig 13. Technical conveniences for e-gamers

\section{Conclusions}

The research conducted and presented so far points to the following conclusions:

- $\quad$ almost all respondents (over 99\% of the sample) in the current study were students, which was reflected in the obtained scores. The older the students, the weaker interest in completing the questionnaire or its findings. It is caused by the increasing number of tasks connected with studies as well as the heavy workload connected with regular or temporary work (nearly $36 \%$ of working students). The latter is confirmed in the scores of other surveys $[14,16,17,26]$, despite the fact that, in total, fewer than $25-16 \%$ students participated in the study (even though it was always the largest group of players),

- $\quad$ among people who completed questionnaires there were markedly more women (almost 60\%) than in other survey studies (around 43-48\%) [25], conducted two or three years ago. Thus, we may conclude that there occurs a specific change with regard to the number of women playing computer games. Naturally, we should also be aware of the fact that the present study examined mainly the responses of students of economic faculties, and in this case the general number of female students in these faculties is greater than men. Still, the survey included also the option I don't play computer games, which the women could indicate,

- $\quad$ the frequency of playing the game (every day, up to a few times a week) in the examined sample was 20 percentage points smaller than in the case of other studies $(39 \%$, as compared to $62-63 \%)$. We should also consider the fact that in the other studies we took into consideration also another large group of potential gamers - pupils the group which ranks second with regard to the number of individuals spending time in the game -. The pupils have more free time than students, especially senior students. 
All in all, majority of players $-54 \%$ of the interviewees, after completing one game, take a break before they start playing another game, and only $14 \%$ immediately start to play another game,

- the vast majority of players use their smartphone to play computer games (over 80\%, mainly Android system - a large number of free games), which does not exclude also simultaneous use of other devices, mainly PC (over 65\%) and a console, a regular $(63 \%)$ or mobile one $(11 \%)$. Smartphones and tablets started to take a role of a PC. Two or three years ago the proportions were more or less reversed; approximately $90 \%$ of respondents $[9,16$, 17] used mainly personal computer, and only half of them a smartphone or a tablet. The devices allow for occasional use of many kinds of generally simple games at any place or time (not just during a break at work using your PC), killing the time while waiting for something else to take place,

- $\quad 97 \%$ of gamers use the games installed on a smartphone or a $\mathrm{PC}$, with a surprisingly low percentage $(10 \%)$ of people using Facebook games,

- due to the dynamic development of the use of smartphones and tablets in the last two years it occurred that the greatest number of people play simple simulation games (over $80 \%$ ) and arcade games $(58 \%)$ and action-adventure games (50\%) which are becoming popular again. When we compare the present research with the earlier studies related to this area [9, 16, 17], the RPG games lost its popularity due to the increasing importance of mobile devices use (here: $44 \%, 65 \%$ - in other studies),

- notably, however, the early age when children start playing computer games, a shift towards younger and younger children (3-4 years younger since 2013) contributes to further development of computer games. More and more frequently it is caused by the fact that the first device with access to games is a smartphone, not a PC, and the fact that smartphones offer a greater number of free game applications,

- $\quad$ in general, the respondents (almost 80\%) are not willing to pay for this kind of entertainment, and, as a vast majority, they use free smartphone applications and computer games which they received for their PC free of charge. It is reflected in the studies concerning the use of smartphones $[1,2]$ and a low tendency among students to spend their earnings on this purpose,

- it also explains the unwillingness to give up other kinds of entertainment, social life or rest to spend one's time in a game: almost $62 \%$ are not interested in choosing a game over any other kind of entertainment, and over $77 \%$ declared that they did not give up any activity in favor of a game last year,

- it appears that the fact that over $70 \%$ respondents claim that the level and quality of computer games fulfill all or almost all their expectations does not impact the situation,

- they have no expectations concerning taking leadership in a game (64\%), they treat the games as a simple, not overly complex, form of entertainment. In general, they play games individually, and they are not interested - at least to a considerable degree - in multiplayer games,

- e-gamers have high opinions about their gaming skills - over $60 \%$ of participants claim that their skills are at least at an advanced level, and only $6 \%$ that they are beginners. On the one hand, it may be caused by the length of time of playing computer games (experience); on the other, it may result from the simplicity of most games that they play,

- the above said phenomenon is the reason why they do not expect too many advantages (none - $28 \%$ ). If they were to choose, they would get help from other users $(22 \%)$ or they would try harder to succeed in the game $(18 \%)$ if they had a chance to obtain a reward or virtual bonus for winning the game,

- the case of technical conveniences is somewhat different. $23 \%$ would like to change their hardware hoping that this way they would have better chances to participate in the existing games and a greater possibility to participate in games of higher technical requirements. They pay attention to better accessories. Less than 3\% would not improve anything as far as technical conditions of gaming are concerned.

The conclusions from the first stage of the research constitute good basis for further studies and expanding their offer, their consequences and impact of using games from the point of view of players. However, the present results already show interesting implications for the development of mobile information technologies towards new development trends of the use of this kind of software as a source of entertainment.

The further research - after preparing discussion and conclusions about sociological and psychological aspects of the gaming (include discussion of perceived positive and negative aspects of being a gamer or attempt to identify of the subcultures of players (the first attempt see [3]) - will focus on the market for suppliers of computer games and video games, in particular delivered to for mobile devices.

Results of a survey may be used not only by researchers in the field of computer games but by computer firms which want to make one step ahead in the development of this phenomenon.

\section{REFERENCES}

[1] Chmielarz W.: Study of Smartphones Usage from the Customer's Point of View, Procedia Computer Science, Elsevier, Vol. 65, 2015, pp. 1085-1094; DOI:10.1016/j.procs.2015.09.045;

[2] Chmielarz W.: Porównanie wykorzystania sklepów internetowych $\mathrm{z}$ aplikacjami mobilnymi $\mathrm{w}$ Polsce $\mathrm{z}$ punktu widzenia klienta 
indywidualnego (Comparison of the Use of Mobile Applications Websites in Poland from the Point of View of Individual Client) in: Innowacje w zarządzaniu i inżynierii produkcji edited by R. Knosala, in: Vol. II, Part IX Inżynieria jakości produkcji i usług, Oficyna Wydawnicza Polskiego Towarzystwa Zarządzania Produkcją, Opole, 2015, pp. 234-245,

[3] Chmielarz W., Szumski O. (2016), Analiza wykorzystania gier komputerowych (Computer Games Application Analysis), in: Mobilne aspekty technologii informacyjnych (Mobile aspects of IT), red. W. Chmielarz, Wydawnictwo Naukowe WZ UW, Warszawa, Dom Wydawniczy Elipsa, pp. 81-106; DOI: 10.7172/978-83-65402-257.2016.wwz.7;

[4] Duggan M. (2015): Gaming and Gamers, at: http://www.pewinternet. org/2015/12/15/gaming-and-gamers/, access, January 2016;

[5] Essential Facts about Computer and Video Games industry, ESA Entertainment Software Association, 2015 at: http://www.theesa. com/wp-content/uploads/2015/04/ESA-Essential-Facts-2015.pdf, access: January, 2016;

[6] Fang X., S. Chan, C. Nair (2009): An Online Survey System on Computer Game Enjoyment and Personality, in: J. A. Jacko (ed.), Human Computer Interactions, Part IV, HCII 2009, LNCS 5613, pp 304-314, Springer Verlag Berlin Heidelberg; DOI:10.1007/978-3-64202583-9 34;

[7] Fromme J., Computer Games as a Part of Children's Culture (2003), The International of Computer Game Research, volume 3, issue 1, 2003, at: http://www.gamestudies.org/0301/fromme/, access, January 2016;

[8] Homo Ludens 1/(2) (2010), Polskie Towarzystwo Badania Gier, access January 2016;

[9] http://akcjonariatobywatelski.pl/pl/centrumedukacyjne/gospodarka/1033,Polski-rynek-gier-komputerowych-natle-rynku-swiatowego.html, access, January 2016;

[10] http://it-pomoc.pl/komputer/gra-komputerowa; access, January 2016;

[11] http:/wiedzaiedukacja.eu/archives/tag/analiza-gier, access, January 2016;

[12] http://www.gry-online.pl/S013.asp?ID=82806; access, January 2016;
[13] http://www.gry-online.pl/S018.asp?ID=208\&STR=2, access, January 2016;

[14] http://www.jestemgraczem.com/wyniki, access, January 2016;

[15] http://www.kipa.pl/index.php/promocja-filmu/grykomputerowe/definicje-gier-komputerowych, access, January 2016

[16] http://www.marketing-news.pl/message.php? $\operatorname{art}=43734, \quad$ access, January 2016;

[17] http://www.newzoo.com/product/global-games-market-reportpremium/, access, January 2016;

[18] https://www.surveymonkey.com/r/2WCW3K9, SurveyMonkey Inc. (US), access, January, 2016;

[19] http://www.survio.com/survey/d/D8Q9F2M7N4E0W5F0P, access, January 2016 ;

[20] https://pl.wikipedia.org/wiki/Gra komputerowa, access January 2016;

[21] Lofgren K. (2015): 2015 Video Game Statistics \& Trends; Who's Playing What \& Why?; at: http://www.bigfishgames.com/blog/2015global-video-game-stats-whos-playing-what-and-why/, access, December 2016;

[22] Mijal M., Szumski O., Zastosowania gier FPS w organizacji, in: Chmielarz W., Kisielnicki J., Parys T. eds), Informatyka@ przyszłości, Wydawnictwo Naukowe WZ UW, Warsaw 2013, pp. 165-176;

[23] Świerczyńska-Kaczor U., J. Wachowicz (2013), Student Response to Educational Games - An Empirical Study, Proceedings of the 2013 FedCSIS, pp. 1293-1299 at: https://fedcsis.org/proceedings/2013/ plics/55.pdf, access, January 2016;

[24] Zajac J.: Jestem graczem w social media, at: http://blog.sotrender.com/p1/2014/12/jestem-graczem-w-social-media/, access, January 2016;

[25] Żywiczyńska E.: Co tak naprawde wiemy o graczach, 2014, at http://zgranarodzina.edu.pl/2014/10/12/co-tak-naprawde-wiemy-ograczach/, access, January 2016 ;

[26] Żywiczyńska E.: Optymizm czy myślenie życzeniowe. Zaskakujące wyniki badania \#jestemgraczem, at: http://zgranarodzina.edu.pl/ 2014/12/20/optymizm-czy-myslenie-zyczeniowe-zaskakujace-wynikibadania-jestemgraczem/, access, January 2016; 